\title{
Molecular cloning and characterization of form I antigen genes of Shigella sonnei
}

\author{
Yoko Yoshida, ${ }^{1 *}$ Noboru OKamura,,${ }^{1,2}$ Junichi Kato $^{3}$ and Haruo Watanabe ${ }^{3}$ \\ ${ }^{1}$ Department of Microbiology, The Institute of Public Health, 4-6-1 Shirokanedai, Minato-ku, Tokyo 108, Japan \\ ${ }^{2}$ School of Allied Health Sciences, Tokyo Medical and Dental University, 1-5-45 Yushima, Bunkyo-ku, Tokyo 113, Japan \\ ${ }^{3}$ Department of Bacteriology, National Institute of Health, 2-10-35 Kamiosaki, Shinagawa-ku, Tokyo 141, Japan
}

(Received 6 September 1990; revised 20 November 1990; accepted 11 December 1990)

\begin{abstract}
Sau3AI-generated DNA fragments of the Shigella sonnei large plasmid encoding the form I antigen were cloned into Escherichia coli with cosmid vector pHSG262. One resulting plasmid, designated pJK1137, was studied further. Restriction endonuclease mapping and analysis of transposon $\mathrm{Tn} 3$ insertion mutants demonstrated that the form I antigen genes were located within a region of about $12.6 \mathrm{~kb}$ consisting of the two contiguous HindIII fragments of $1.26 \mathrm{~kb}$ and $12.4 \mathrm{~kb}$. The results of complementation studies between $\mathrm{Tn} 3$ insertion mutants of pJK1137 and recombinant plasmids carrying different parts of the form I antigen genes indicated that the $12.6 \mathrm{~kb}$ DNA sequence contained at least four gene clusters, regions A, B, C and D. Analysis of radioactively labelled proteins in minicells demonstrated that the DNA sequence of about $12.6 \mathrm{~kb}$ coded for at least four specific proteins of $42,23,48$ and $39 \mathrm{kDa}$. The former two were coded by region $\mathrm{A}$, the latter two by region $\mathrm{D}$.
\end{abstract}

\section{Introduction}

Diarrhoeal disease is a major cause of morbidity and mortality worldwide, especially in developing countries. Shigella remains one of the most important causes of diarrhoeal disease. Although the number of Shigella infections has been reduced over the past several decades, a considerable number of cases, most of them travellers returning from overseas, still occur annually in Japan. Shigella sonnei, one of the four species of this genus, is currently responsible for more than half of the shigellosis cases reported in Japan.

Bacteria of the genus Shigella produce, via the processes of penetration, multiplication and intercellular dissemination, an infection that is normally limited to the epithelial cells of the colon and that results in bloody and/or mucous diarrhoea. Previous genetic studies of Shigella flexneri have revealed that virulence in this species is multideterminant, with plasmid-encoded and widely separated chromosomal regions being required (Sansonetti et al., 1983). In addition to the attributes responsible for epithelial cell penetration and multiplication, the somatic $\mathrm{O}$ antigen is also important for virulence in Shigella (Okamura et al., 1983; Sansonetti et al., 1981, 1983). Earlier studies on vaccination (DuPont et al., 1969; Formal et al., 1966; Mel et al., 1965) indicated that protection against bacillary dysentery is associated with $\mathrm{O}$ antigen specificity. Although it is known that the somatic $\mathrm{O}$ antigen is one of the virulence factors and induces a protective immune response in humans, it is still unclear how the $\mathrm{O}$ antigen participates in the pathogenesis of Shigella infection.

All virulent Shigella sonnei strains, unlike other Shigella species, comprise a single serotype which produces smooth colonies expressing a somatic antigen termed form I. This antigenic specificity corresponds to the $\mathrm{O}$ side chains of the lipopolysaccharide layer, which are composed of disaccharide repeating subunits containing two unusual amino sugars (Kenne et al., 1980; Gamian \& Romanowska, 1982). These smooth colonies are usually unstable and dissociate to rough-appearing colonies termed form II, which are uniformly avirulent. Unlike the majority of the species of the family Enterobacteriaceae, in which $\mathrm{O}$ antigen genes are located on the bacterial chromosome, in S. sonnei (Kopecko et al., 1980) and in a strain of Escherichia coli O111 (Riley et al., 1987) the complete $O$ antigen genes are plasmidborne. Previous reports have demonstrated that a large $120 \mathrm{MDa}$ plasmid of $S$. sonnei is unique in that it is responsible not only for the ability to penetrate epithelial cells (Sansonetti et al., 1981), but also for the expression of the form I antigen (Kopecko et al., 1980).

In the present study, we cloned the form I antigen genes from a DNA library of the large plasmid of $S$. 
sonnei and characterized these genes by transposoninsertion mutagenesis and complementation studies.

\section{Methods}

Bacterial strains and plasmids. Shigella sonnei form I strain HW383 harbouring pSS120 (Watanabe \& Nakamura, 1985) was used as a source of form I DNA. A form II strain, S. sonnei HW 506, was obtained by curing $S$. sonnei HW 383 of pSS120. Escherichia coli strains HB101 (hsd $22 O$ recAl3 ara proA lacY galK rpsL $x y l$ mtl supE) (Boyer \& Roulland-Dussoix, 1969), JM109 (recA endA gyrA thi hsdRI7 supE relAl $\Delta($ lac-proAB $) / \mathrm{F}^{\prime}\left[\right.$ proA $^{+} B^{+}$lacla lacZ $\Delta M 15$ traD $]$ ) (YanischPerron et al., 1985) and K12 921 (Yoshimori et al., 1972) were used as recipients in transformation. E. coli $\mathrm{TH} 1219\left(\mathrm{~F}^{-} \operatorname{minB}\right.$ recAl rpsL tsr tar) (Harayama \& Hazelbauer, 1982) is a minicell-producing strain of E. coli K12. DNAs of pUC18 (Yanisch-Perron et al., 1985), pACYC184 (Chang \& Cohen, 1978), pBR322 (Maniatis et al., 1982) and cosmid pHSG262 (Brady et al., 1984) were used for cloning. The plasmid pKDEC100 (kindly supplied by Dr H. Danbara, Kitasato Institute), used as the $\operatorname{Tn} 3$ transposon donor, is a thermosensitivereplication mutant of pHSG415 (Hashimoto-Gotoh et al., 1981). Most of the other plasmids were prepared in this study.

Media and reagents. Bacteria were grown in L-broth (Lennox, 1955) or on plates of Antibiotic medium no. 3 (PAB; Difco) with $1.5 \%$ (w/v) agar. The following antibiotics were used: ampicillin (Ap), kanamycin $(\mathrm{Km})$, chloramphenicol $(\mathrm{Cm})$ and tetracycline $(\mathrm{Tc})$. Restriction enzymes were purchased from Toyobo.

Preparation of antigen. For immunization of rabbits and preparation of the agglutination antigens, test strains were cultivated on PAB agar plates. The organisms were harvested from agar plates in $0.85 \%$ sterile saline. For use as vaccines, formalin $(0.3 \%, \mathrm{v} / \mathrm{v})$ killed cells were diluted in sterile saline to a density of approximately $1 \times 10^{9}$ organisms $\mathrm{ml}^{-1}$. For use in the agglutination test, the formalin- or heat-killed cells were standardized in sterile saline to an $\mathrm{OD}_{650}$ of 0.4 .

Preparation of antisera. Young, male rabbits, each weighing 3 to $4 \mathrm{~kg}$, were used. Intravenous injections of the vaccine were given twice weekly. The doses were $0.25,0.5,1.0$ and $1.5 \mathrm{ml}$, respectively, for the first 2 weeks and $2.0 \mathrm{ml}$ each for the last four doses. At 1 week after the last injection, blood was collected aseptically and serum was obtained.

Absorption of antisera. Formalin- or heat-treated packed cells $(100 \mathrm{mg})$ were added to $1.0 \mathrm{ml}$ of undiluted or 10 -fold diluted antiserum. The antiserum/cell suspensions were mixed and incubated in a $37^{\circ} \mathrm{C}$ water bath for $2 \mathrm{~h}$, followed by overnight incubation at $4{ }^{\circ} \mathrm{C}$. The absorbed antiserum was collected by centrifugation.

Slide agglutination test. For most of the antigenic analysis of form I and form II antigens, slide agglutination tests were done using the commercial form I and form II antigen-specific rabbit antisera (DenkaSeiken).

Quantitative agglutination test. Serial dilutions $(0.5 \mathrm{ml})$ starting at a 1:10 dilution of serum were mixed in test tubes with $0.5 \mathrm{ml}$ of a suspension of whole cells of $S$. sonnei. The tubes were kept at $37^{\circ} \mathrm{C}$ for $2 \mathrm{~h}$ and at $4^{\circ} \mathrm{C}$ overnight. Endpoints were taken as the reciprocal of the highest dilution of serum to give complete agglutination of the bacterial suspension by comparison with a negative saline control.

Construction of a gene library of $S$. sonnei form I plasmid DNA. The methods used for cosmid cloning were essentially as described by Maniatis et al. (1982). Form I plasmid DNA of the 120 MDa plasmid in S. sonnei HW383, prepared as described previously (Watanabe \&
Nakamura, 1986), was partially digested with restriction endonuclease Sau3AI, and fragments in the size range 30 to $50 \mathrm{~kb}$ were isolated by sucrose density-gradient centrifugation. These fragments were ligated into the BamHI site of cosmid vector pHSG262. Clones of E. coli HB101 harbouring cosmids containing insertions of form I antigen genes were examined by the slide agglutination test.

Recombinant DNA methods. Rapid isolation of plasmid DNA was performed by the method of Birnboim \& Doly (1979). When necessary, plasmid DNA was further purified by ultracentrifugation in caesium chloride/ethidium bromide density gradients. Restriction-endonuclease-cleaved DNA was analysed by electrophoresis through horizontal $0.7 \%(\mathrm{w} / \mathrm{v})$ agarose gels or vertical $3.5 \%(\mathrm{w} / \mathrm{v})$ polyacrylamide gels in TBE buffer ( $89 \mathrm{mM}$-Tris base, $89 \mathrm{~mm}$-boric acid, $2.5 \mathrm{~mm}$-disodium EDTA, pH 8.3) or E buffer ( $40 \mathrm{~mm}$-Tris, 2 mm-disodium EDTA pH 7.9) (Kado \& Liu, 1981). Restriction fragments of DNAs of phages $\lambda$ and $\phi \mathrm{X} 174$ were used as molecular markers. Restriction fragments of DNA were isolated from low-melting agarose gel (Sea plaque Agarose, FMC) as described by Weislander (1979). Ligation was performed using a Takara ligation kit at $16^{\circ} \mathrm{C}$ for $1 \mathrm{~h}$. Transformation with ligated DNA was carried out according to the procedure of Mandel \& Higa (1970).

Tn3 insertion mutagenesis. E. coli $\mathrm{HB} 101$ harbouring both pJK 1137 and pKDEC 100 was preincubated in PAB containing both Ap $(100 \mu \mathrm{g}$ $\left.\mathrm{ml}^{-1}\right)$ and $\mathrm{Km}\left(50 \mu \mathrm{g} \mathrm{ml}^{-1}\right)$ at $30^{\circ} \mathrm{C}$. The culture was spread on PAB agar plates containing both $\mathrm{Ap}\left(500 \mu \mathrm{g} \mathrm{ml}^{-1}\right)$ and $\mathrm{Km}\left(100 \mu \mathrm{g} \mathrm{ml}^{-1}\right)$ and incubated at $43^{\circ} \mathrm{C}$. The resulting colonies were purified three times on the same medium at $43^{\circ} \mathrm{C}$.

Analysis of lipopolysaccharide ( $L P S)$. LPS from whole-cell lysates was prepared by the procedure of Hitchcock \& Brown (1983), and subjected to SDS-PAGE ( $12 \%$ acrylamide), using the buffer system of Laemmli (1970). LPS bands were visualized by silver staining (Hitchcock \& Brown, 1983).

Analysis of plasmid-encoded proteins in minicells. Preparation and labelling of minicells were performed essentially as described previously (Kato et al., 1984). The labelled proteins were subjected to SDSPAGE and autoradiographed.

\section{Results}

\section{Gene bank of the form I antigen genes}

Sau3AI-generated DNA fragments of pSS120 were cloned into E. coli $\mathrm{HB} 101$ with cosmid vector pHSG262. Nine out of 260 clones harbouring recombinant cosmids were found to express form I antigen as determined by the slide agglutination test. Two of the form I-antigenpositive recombinant clones, designated HB101(pJK1137) and HB101(pJK1139), were selected for further study. Both these clones agglutinated with form I antiserum at the same level as $S$. sonnei HW383(pSS120). Stability of the recombinant plasmids was tested in E. coli HB101, after incubation in Penassay broth for about 15 generations at $37^{\circ} \mathrm{C}$ without $\mathrm{Km}$. pJK1137 was maintained in the host strain at a frequency of $70 \%$, whereas pJK 1139 was unstable, being maintained at a frequency of only $15 \%$. 


\section{Quantitative agglutination test}

S. sonnei HW383 and HW506(pJK1137), a transformant of HW506 with pJK1137, both of which agglutinated strongly with form I antiserum in the slide agglutination test, were used to immunize rabbits and antisera were obtained. The antisera were then used in reciprocal agglutinin absorption tests, with formalin- or heat-killed bacterial cells as antigens. The results suggested that the two strains shared an identical form I O antigen (Table 1). The polyclonal sera we used (even in the absorbed anti-HW383 sera) may have contained antibodies against the virulence-associated proteins encoded by the virulence plasmid. However, even with relatively high agglutination titres of serum, the virulence-associated proteins are not detected by agglutination tests (LaBrec et al., 1964), and Shigella has no $\mathrm{H}$ antigens and few K antigens. We therefore conclude that we are looking mostly at the $\mathrm{O}$ antigens by the agglutination test.

\section{Analysis of LPS by SDS-PAGE}

To confirm the results of the agglutination tests, these isogenic strains were examined for LPS structure by SDS-PAGE. pJK 1137 expressed in E. coli and S. sonnei similar patterns of O-specific or ladder bands in SDSPAGE as those of the wild-type HW383 (Fig. $1 a$, lane 4; Fig. $1 b$, lanes 4 and 5). In contrast, the form II strain HW506 retained only the low-molecular-mass band that may represent all or part of the polysaccharide core unit conjugated to lipid A (Fig. 1b, lane 6).

Restriction cleavage analysis of the recombinant plasmids harbouring form I antigen genes

Two of the recombinant plasmids described above were analysed with the restriction enzymes EcoRI, SalI, $H$ indIII and $B g l$ II. Both of the plasmids, after cleavage with HindIII, yielded a common $12.4 \mathrm{~kb}$ fragment, which consisted of $B g l$ II fragments of 5.3, 1.66, 0.68 , 0.66 , and $0.72 \mathrm{~kb}$, and $H$ indIII-BglII fragments of 2.6 and $0.78 \mathrm{~kb}$ (Fig. 2). On the basis of the above results, we speculated that the $12.4 \mathrm{~kb}$ HindIII fragment might contain all the genes encoding form I antigen. Therefore, the $12.4 \mathrm{~kb}$ HindIII fragment of pJK 1137 was cloned into the HindIII site of pBR322, and the resulting recombinant plasmid pIP35 was used to transform strains HB101 and HW506. However, the transformed strains did not direct the synthesis of active form I antigen (Fig. 2). To define the whole region of form I antigen genes on the recombinant plasmid, pJK1137 DNA was subjected to detailed restriction cleavage analysis. The restriction endonuclease cleavage map of pJK1137 is shown in Fig 2.
Table 1. Reciprocal agglutinin absorption test

The results were the same regardless of whether the antigens were formalin- or heat-killed.

\begin{tabular}{cccc}
\hline \hline & \multicolumn{2}{c}{ Agglutinin titre against } \\
\cline { 3 - 4 } $\begin{array}{c}\text { Antiserum } \\
\text { prepared against }\end{array}$ & $\begin{array}{c}\text { Absorption } \\
\text { with }\end{array}$ & HW383 & $\begin{array}{c}\text { HW506 } \\
\text { (pJK1137) }\end{array}$ \\
\hline HW383 & - & 1280 & 1280 \\
& $\begin{array}{c}\text { HW506 } \\
\text { (pJK1137) }\end{array}$ & $<20$ & $<20$ \\
HW506 & - & 640 & 640 \\
(pJK1137) & HW383 & $<20$ & $<20$ \\
\hline \hline
\end{tabular}

-, Unabsorbed.

Isolation of form I antigen-negative Tn3 insertion mutants of $p J K 1137$

Using a thermosensitive-replication mutant of pKDEC100 carrying transposon $\mathrm{Tn} 3$, we constructed Tn 3 insertion mutants of $\mathrm{pJK} 1137$. The insertion sites of Tn 3 were assigned to each of the HindIII fragments after cleavage analysis with HindIII. Of 60 form I antigennegative Tn 3 insertion mutants obtained, 58 contained Tn 3 molecules within a $12.4 \mathrm{~kb}$ HindIII fragment, the remaining two within the $1.26 \mathrm{~kb}$ HindIII fragment (Figs 2 and 3). The Tn 3 insertions into HindIII fragments of $17 \cdot 7,6 \cdot 0$ and $1.26 \mathrm{~kb}$ were identified as being form I antigen-positive. We could not detect form I antigenpositive strains with $\operatorname{Tn} 3$ inserted into the $12.4 \mathrm{~kb}$ HindIII fragment. The results indicated that form I antigen genes were located at least on the contiguous HindIII fragments of 1.26 and $12.4 \mathrm{~kb}$ (Figs 2 and 3 ). The precise positions of $\mathrm{Tn} 3$ insertions in plasmid pJK 1137 were determined on some of the plasmids with or without form I antigen production by calculating the sizes of SalI-BamHI and HindIII-BamHI fragments of the respective plasmids. SalI and HindIII have no cleavage site on Tn3, and BamHI has only one cleavage site on $\mathrm{Tn} 3$ and no cleavage site on pJK1137. Some of the Tn3 insertions, which are indicated as pIP, are shown in Fig. 3. Of 30 form I antigen-negative plasmids, 22 had $\operatorname{Tn} 3$ insertions in the regions between the Tn 3 insertion site of pIP2 and that of pIP4, and one into the same site as pIP1. On the other hand, one of the form I antigen-positive plasmids, designated pIP30, had Tn3 inserted about $0.2 \mathrm{~kb}$ from one end of the cosmid vector DNA (Fig. 3). Another form I antigen-positive plasmid, designated pIP31, had Tn 3 inserted about $1.6 \mathrm{~kb}$ from one end of the $12.4 \mathrm{~kb}$ HindIII fragment (Fig. 3). These results indicated that the region indispensable for biosynthesis of form I antigen is located on the region of about $14.2 \mathrm{~kb}$ between the Tn 3 insertion sites of pIP30 and pIP31 (Fig. 3). 
(a)

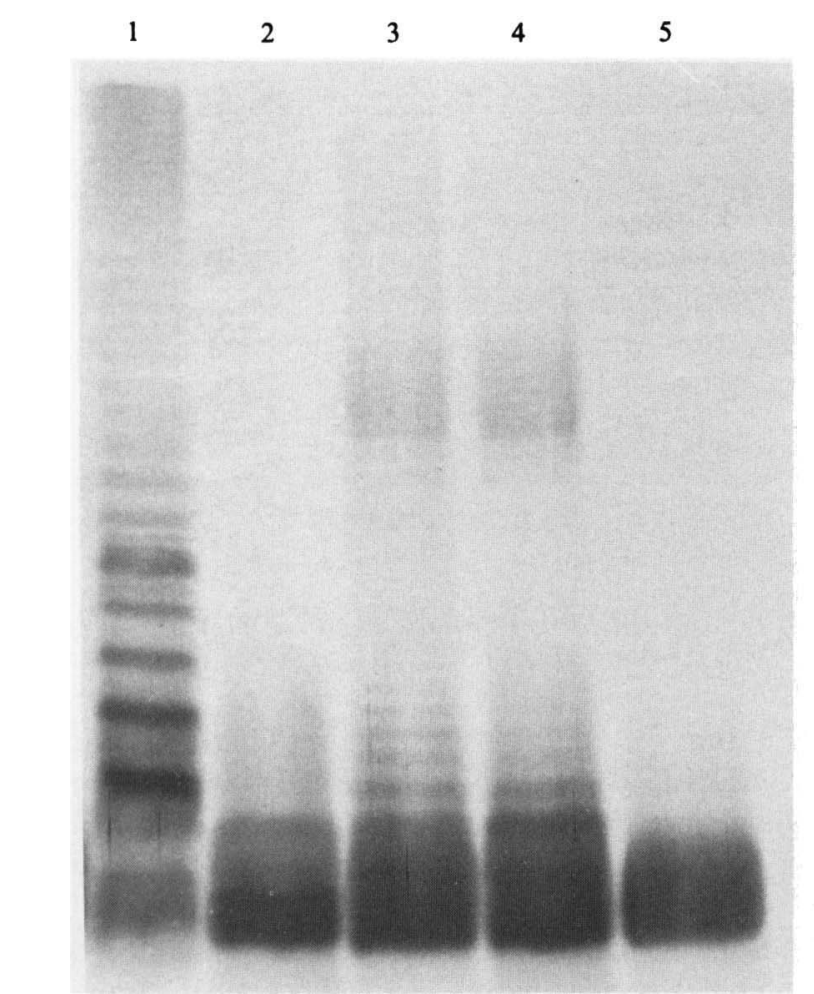

(b)

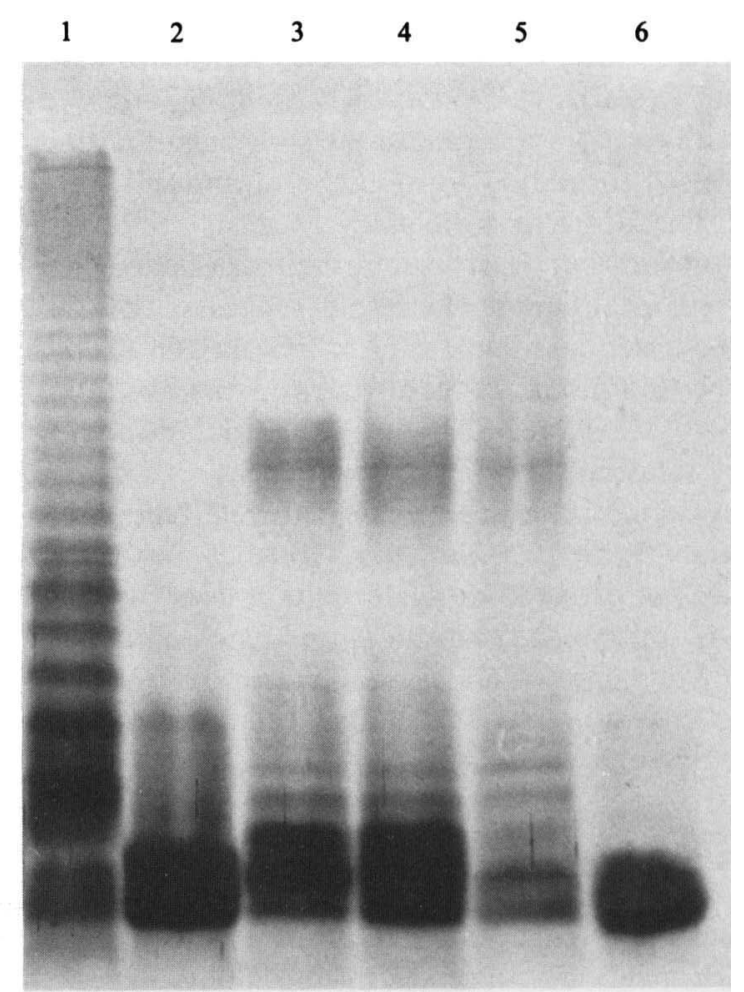

Fig. 1. SDS-PAGE patterns of the LPS of form I antigen-positive and -negative strains. Whole-cell lysates treated with proteinase $\mathrm{K}$ were subjected to SDS-PAGE and detected by silver staining. Lanes: (a) 1 , Salmonella typhimurium LT-2 as a standard; 2 , E. coli HB101(pIP6); 3, HB101(pIP36); 4, HB101(pJK1137); 5, HB101. (b) 1, LT-2; 2, S. sonnei HW506(pIP6); 3. HW506(pIP36); 4, HW506(pJK 1137); 5, S. sonnei HW383; 6, HW506.

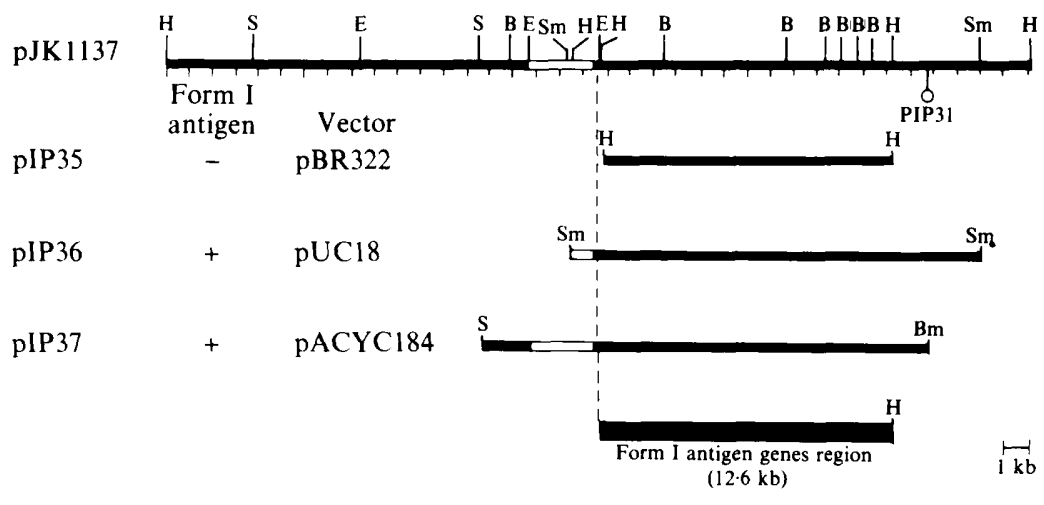

Fig. 2. Restriction cleavage map of pJK1137 and subcloning of form I antigen genes. The upper part of the figure shows the restriction map of pJK 1137. The cosmid vector pHSG262 is shown by the open box The following enzymes were used: $\mathrm{H}$, HindIII; B, $B g l \mathrm{II} ; \mathrm{Bm}$, BamHI; E, EcoRI; S, SalI; Sm, SmaI. The unique BamHI site was only assigned onto the transposon Tn3. A $12.4 \mathrm{~kb}$ HindIII fragment and a $17.8 \mathrm{~kb}$ SmaI fragment of pJK 1137 were cloned into the vector plasmids pBR322 and pUC18 respectively. Insertion of transposon $\mathrm{Tn} 3$ into the $6.0 \mathrm{~kb}$ HindIII fragment (plasmid pIP31) of pJK 1137 (Fig. 3) did not affect the form I antigen-positive phenotype (open circle). A SalI-BamHI fragment of $20.7 \mathrm{~kb}$ prepared from pIP31 was also cloned into the vector pACYC184. The minimum size of form I antigen regions estimated in this study is shown at the bottom by a thick bar. +, Form I antigen-positive; - , form I antigen-negative.

Subcloning of essential genes for the synthesis of S. sonnei form I antigen

As a first step in subcloning the form I antigen genes, a $17.8 \mathrm{~kb}$ SmaI fragment of pJK 1137, which contained the complete form I antigen region along with a $1.2 \mathrm{~kb}$ portion of cosmid vector pHSG262 DNA, was cloned into the SmaI site of the plasmid vector pUC18. The recombinant plasmid, designated pIP36, produced the form I antigen in the E. coli $\mathrm{HB} 101$ and $S$. sonnei $\mathrm{HW} 506$ (Fig. 1a, b, lanes 3; Fig. 2). A second recombinant plasmid, designated pIP37, was a pACYC184-ligated 


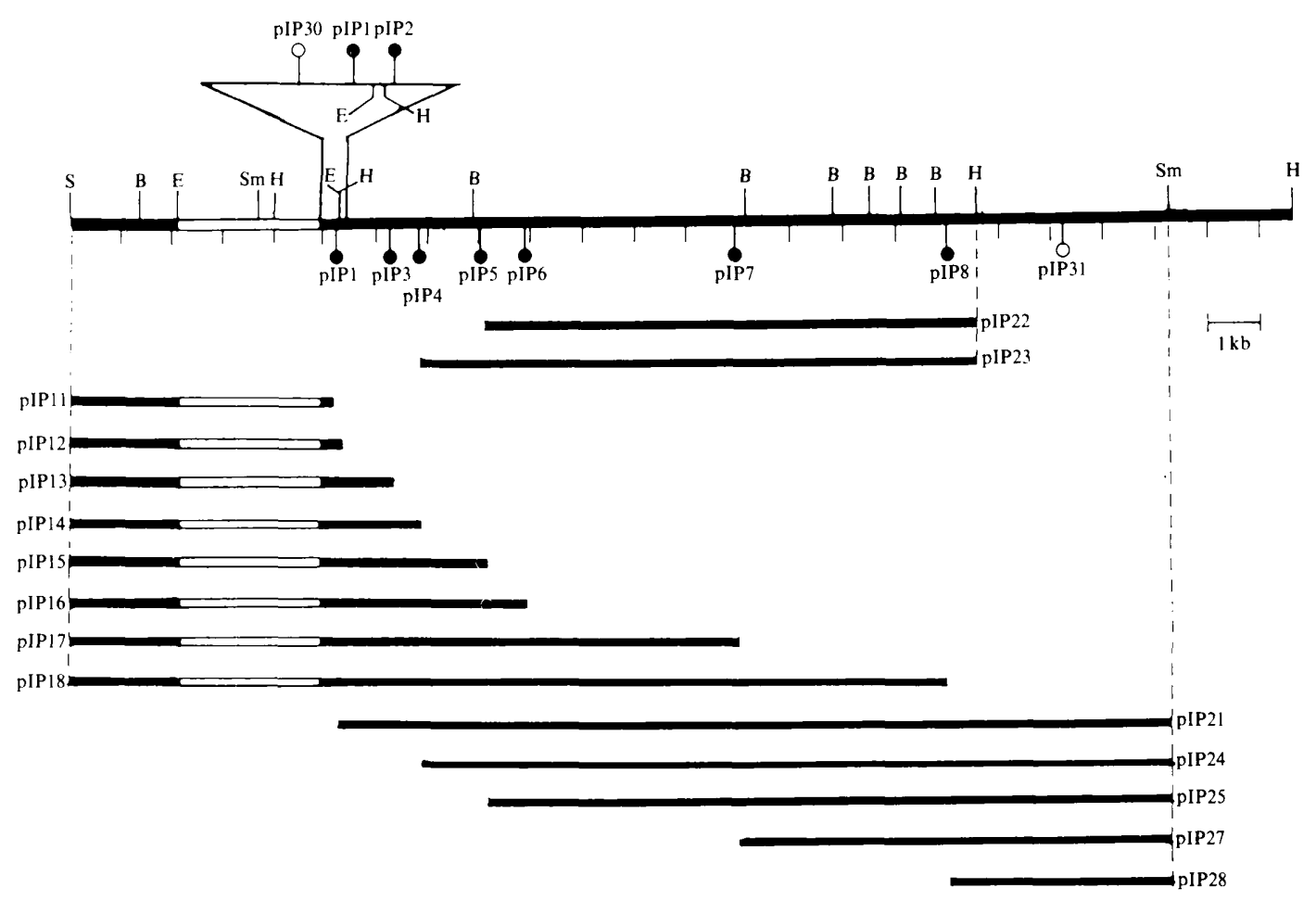

Fig. 3. The physical location of Tn 3 insertions on the three contiguous HindIII fragments of pJK1137, and the recombinant plasmids prepared for the complementation studies. Plasmids marked with open circles and solid circles were positive and negative for form I antigen, respectively. The other symbols are as in the legend to Fig. 2. The Sal I-BamHI fragments of Tn3 insertion mutants of pJK 1137 were cloned into the SalI-BamHI site of pACYC184. The SmaI-BamHI fragments of Tn3 insertion mutants of pJK 1137 were cloned into the HincII-BamHI site of pACYC184. HindIII-BamHI fragments of pIP5 and pIP4 were also cloned into the HindIII-BamHI site of pACYC184, and the resulting plasmids were designated pIP22 and pIP23 respectively. The region of Tn 3 insertion sites of pIP30, pIP1 and pIP2 is enlarged.

recombinant of the $20.7 \mathrm{~kb}$ SalI-BamHI fragment prepared from the form I antigen-positive plasmid pIP31. StrainsHB101 and HW506 harbouring pIP37 also produced the form I antigen (Fig. 2). We then tried to determine whether the $6.0 \mathrm{~kb}$ HindIII fragment is necessary for expression of the form I antigen. The plasmids pIP22 and pIP23 (Fig. 3), in which the BamHIHindIII fragment of pIP5 and pIP4 had been cloned into the vector pACYC184 respectively, were separately introduced into $E$. coli $\mathrm{K} 12921$ carrying a resident plasmid pIP17 or pIP18 (Fig. 3) by selection for resistances to $\mathrm{Ap}, \mathrm{Cm}$ and $\mathrm{Km}$. In this experiment, neither of the plasmids contained the $6.0 \mathrm{~kb}$ HindIII fragment. The E. coli strain harbouring both pIP22 and pIP17 (or pIP18) directed the synthesis of form I antigen. Similar results were obtained with the strain harbouring both pIP23 and pIP17 (or pIP18). These results showed that the $6.0 \mathrm{~kb}$ HindIII fragment is not essential for form I antigen production. We concluded that the essential genes for form I antigen synthesis are located on the region of about $12.6 \mathrm{~kb}$ in length and ranged in the two contiguous HindIII fragments of $1.26 \mathrm{~kb}$ and $12.4 \mathrm{~kb}$ (Fig. 2).
Complementation studies between Tn 3 insertion mutants of pJK1137 and recombinant plasmids carrying different parts of the form I antigen genes

The related gene clusters of form I antigen synthesis were estimated by complementation studies between $\operatorname{Tn} 3$ insertion mutants of pJK 1137 and recombinant plasmids carrying different parts of the form I antigen genes. As a first step, we obtained the recombinant plasmids pIP11pIP18 by isolating through electrophoresis in a lowmelting agarose gel the Sal I-BamHI fragments of the eight different Tn3 insertion mutants (pIP1-pIP8) of pJK 1137 and ligating them into the SalI-BamHI site of vector pACYC184 (Fig. 3). By the same procedure, we also obtained the recombinant plasmids pIP21, pIP24, pIP25, pIP27 and pIP28, in which SalI-BamHI fragments of pIP1, pIP4, pIP5, pIP7 and pIP8, respectively, were cloned into the vector pACYC184 (Fig. 3). Complementation studies were carried out on $S$. sonnei HW506 (form II). Strains of HW506 independently harbouring one of eight different $\mathrm{Tn} 3$ insertion mutants of pJK1137 were super-infected with each of the recombinant plasmids by selection for resistances to Ap, 


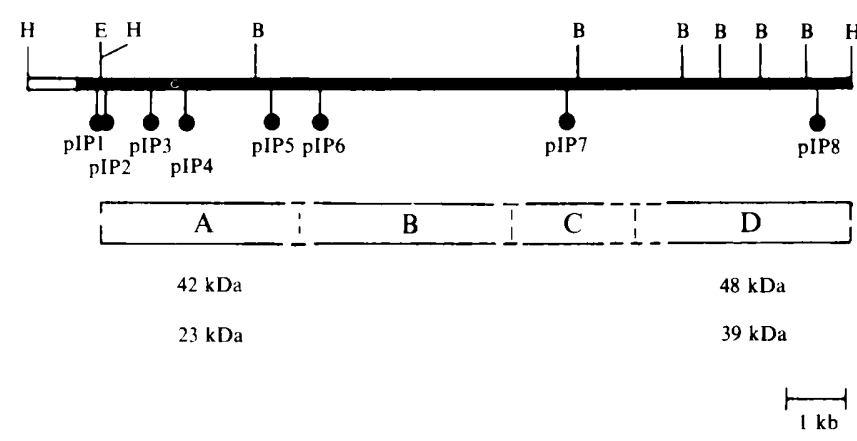

Fig. 4. Summary of gene clusters for biosynthesis of form I antigen derived from the results presented in this study. The approximate boundaries of the regions $\mathrm{A}, \mathrm{B}, \mathrm{C}$ and $\mathrm{D}$ were determined by the complementation studies (Table 2). The sizes of the proteins encoded by genes in regions $A$ and $D$ are indicated. Proteins encoded by regions $\mathrm{C}$ and $\mathrm{D}$ were not identified in this study. The symbols are as in the legend to Fig. 3.

Table 2. Results of complementation tests between Tn3 insertion mutants of pJK1137 and plasmids carrying different parts of the form I antigen genes

\begin{tabular}{|c|c|c|c|c|c|c|c|c|}
\hline \multirow{2}{*}{$\begin{array}{l}\text { Super- } \\
\text { infected } \\
\text { plasmid }\end{array}$} & \multicolumn{8}{|c|}{ pJK $1137:: \operatorname{Tn} 3$ in HW506 } \\
\hline & pIPI & pIP2 & pIP3 & pIP4 & pIP5 & pIP6 & pIP7 & pIP8 \\
\hline pIP11 & - & - & - & - & - & - & - & - \\
\hline pIP12 & - & - & - & - & - & - & - & - \\
\hline pIP13 & - & - & - & - & - & - & - & - \\
\hline pIP14 & - & - & - & - & - & - & - & - \\
\hline pIP15 & - & - & - & - & - & - & - & - \\
\hline pIPl6 & + & + & + & + & + & - & - & - \\
\hline pIP17 & + & + & + & + & + & + & - & - \\
\hline pIP18 & + & + & + & + & + & + & + & - \\
\hline pIP28 & - & - & - & - & - & - & - & - \\
\hline pIP27 & - & - & - & - & - & - & - & \pm \\
\hline pIP24 & - & - & - & - & - & + & + & $\bar{t}$ \\
\hline pIP21 & - & - & - & - & - & + & + & + \\
\hline
\end{tabular}

,+ Agglutination; \pm , weak agglutination;,- no agglutination.

$\mathrm{Km}$ and $\mathrm{Cm}$, and transformants thus obtained were then examined for form I antigen production. The results of the complementation tests are summarized in Table 2. When each of the recombinant plasmids, pIP11, pIP12, pIP13, pIP14 and pIP15, was independently introduced into HW506 harbouring one of the Tn3 insertion mutants, none of the transformants could synthesize active form I antigen. pIP16 restored the synthesis of form I antigen of HW506 harbouring the Tn3 insertion mutant plasmids pIP1, pIP2, pIP3, pIP4, or pIP5. Plasmids pIP17 and pIP18 complemented pIP6 and pIP7, respectively. Similar results were obtained with complementation tests between recombinant plasmids pIP21-pIP28 and the Tn3 insertion mutants (Table 2). The results of our complementation studies suggested that the form I antigen genes within the two contiguous
HindIII fragments of $1.26 \mathrm{~kb}$ and $12.4 \mathrm{~kb}$ are composed of at least four gene clusters (Fig. 4).

Identification in minicells of proteins determined by form I antigen genes

The recombinant plasmids carrying different parts of the form I antigen regions were used to transform the minicell-producing strain TH1219 to determine the proteins encoded by the recombinant plasmids. Extracts of $\left[{ }^{35} \mathrm{~S}\right]$ labelled minicells were subjected to SDS-PAGE and autoradiographed. Two plasmids, pJK1137 and pIP37, which comprised the entire form I antigen genes, synthesized four specific proteins of apparent molecular mass 48, 42, 39, and $23 \mathrm{kDa}$ (Fig. 5). The recombinant plasmid pIP35, which contained the $12.4 \mathrm{~kb}$ HindIII fragment in the vector $\mathrm{pBR} 322$, also synthesized the four proteins of the same sizes as those of pJK1137 and pIP37. From the results of the autoradiographs of the SDS-PAGE, we could not find any intrinsic difference between the proteins encoded by the plasmids pJK 1137 and pIP35, although the former was form I antigenpositive, while the latter was form I antigen-negative. The plasmids pIP13, pIP14 and pIP15, comprising defective A region (Figs 3 and 4), did not direct the synthesis of any specific proteins, whereas the plasmid pIP16, carrying only intact A region (Figs 3 and 4), directed the synthesis of two proteins of $42 \mathrm{kDa}$ and $23 \mathrm{kDa}$. On the other hand, plasmid pIP27, which contained an intact $\mathrm{D}$ region (Figs 3 and 4 ) directed synthesis of the proteins of $48 \mathrm{kDa}$ and $39 \mathrm{kDa}$ (data not shown). We could not identify precisely the products encoded by the $\mathrm{B}$ and $\mathrm{C}$ regions.

\section{Discussion}

The DNA fragments we have cloned appear to be essential and sufficient for full expression of $S$. sonnei form I antigen. Results of the reciprocal agglutinin absorption test and analysis of LPS by SDS-PAGE suggested that the DNA fragments we cloned in the vector plasmid expressed as much form I antigen as did the wild-type strain. However, detailed chemical analysis of the outer-membrane LPS of these strains should be done and is now under way. The present studies revealed that, in the $S$. sonnei large plasmid, there are several genes that are required for form I antigen production. The results also suggested that these genes are organized into at least four gene clusters (or operons). For unknown reasons it was found more suitable to use a $S$. sonnei form II strain than to use E. coli $\mathrm{HB} 101$ as a host strain for the plasmids in the complementation studies. The fact that the form I antigen consists of at least four disaccharide 


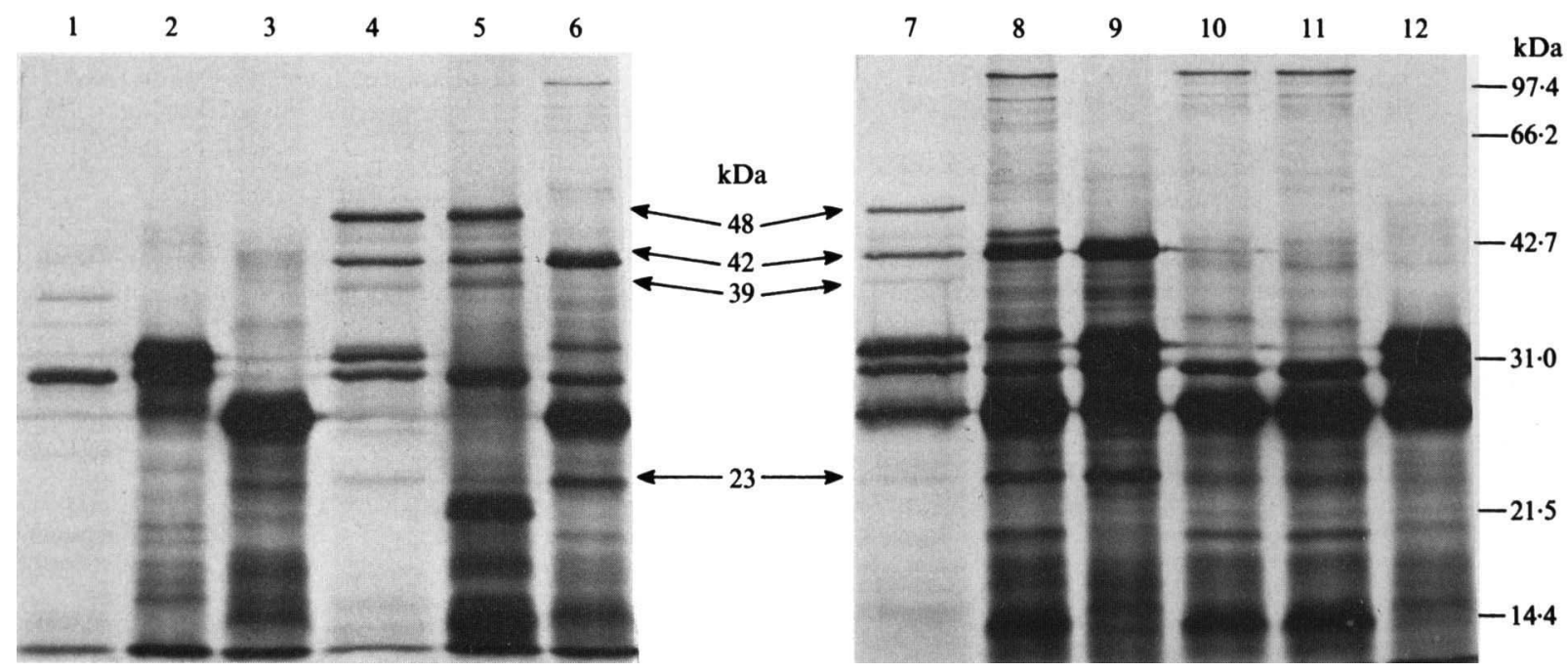

Fig. 5. Identification of the proteins encoded by form I antigen genes. E. coli TH1219 minicells containing the plasmid indicated were incubated with $\left[{ }^{35}\right.$ S]methionine $\left(1000 \mathrm{Ci} \mathrm{mmol}^{-1} ; 37 \mathrm{Tbq} \mathrm{mmol}^{-1}\right)$ for $15 \mathrm{~min}$ and the labelled proteins were separated on SDSpolyacrylamide gels ( $12 \%$ acrylamide) and autoradiographed. Proteins encoded by form I antigen genes are marked with arrows, indicating their apparent molecular masses. The minicells contained the following plasmids: cosmid vector pHSG262 (lane 1 ), pBR322 (lane 2), pACYC184 (lane 3), pIP35 (lane 4), pJK 1137 (lane 5), pIP18 (lane 6), pIP37 (lane 7), pIP17 (lane 8), pIPI6 (lane 9), pIP15 (lane 10), pIP14 (lane 11), and pIP13 (lane 12). The following molecular mass markers (Bio-Rad), indicated on the right, were used: rabbit muscle phosphorylase $b(97.4 \mathrm{kDa})$, bovine serum albumin $(66.2 \mathrm{kDa})$, hen egg white ovalbumin $(42.7 \mathrm{kDa})$, bovine carbonic anhydrase $(31 \mathrm{kDa})$, soybean trypsin inhibitor $(21.5 \mathrm{kDa})$, hen egg white lysozyme (14.4 kDa).

repeating units (Gamian \& Romanowska, 1982) suggested that the form I antigen genes are complex and consist of a number of biosynthetic and regulatory genes. The minicell analysis showed that there are four specific polypeptides encoded by form I antigen genes, two by the A region and another two by the $D$ region. We could not, however, detect any polypeptide bands specific for the B and $C$ regions. This may be attributed partly to the relatively large sizes of the form I gene fragments tested for minicell analysis. We are now doing DNA sequencing studies on these fragments of form I antigen genes.

It is documented that persons who recover from Shigella infections appear to have serotype-specific immunity (DuPont et al., 1969; Mel et al., 1965). However, it is still unclear what kind of immunity to $\mathrm{O}$ antigen is protective against Shigella infection, although serum antibodies or secretory antibodies produced at mucosal surfaces may be important. The results presented here may also provide prospects for a new and effective Shigella vaccine.

This work was supported by a Grant-in-Aid for Scientific Research (no. 62304036) from the Ministry of Education, Science, and Culture of Japan, and by the US-Japan Medical Science Program Cholera Panel.

We express our gratitude to $M$. Ueda, S. Nakajima, K. Kawahara and $H$. Danbara for their technical advice and suggestions.

\section{References}

Birnboim, H. C. \& Doly, J. (1979). A rapid alkaline extraction procedure for screening recombinant plasmid DNA. Nucleic Acids Research 7, 1513-1523.

BOYER, H. W. \& Roulland-Dussorx, D. (1969). A complementation analysis of the restriction and modification of DNA in Esherichia coli. Journal of Molecular Biology 41, 459-472.

Brady, G., Jantzen, H. M., Bernard, H. U., Brown, R., Schütz, G. \& HASHIMOTO-GoTOH, T. (1984). New cosmid vectors developed for eukaryotic DNA cloning. Gene 27, 223-232.

Chang, A. C. Y. \& Cohen, S. N. (1978). Construction and characterization of amplifiable multicopy DNA cloning vehicles derived from the p15A cryptic miniplasmid. Journal of Bacteriology 134, 1141-1156.

DuPont, H. L., Hornick, R. B., Dawkins, A. T., SNyder, M. J. \& FormaL, S. B. (1969). The response of man to virulent Shigella flexneri 2a. Journal of Infectious Diseases 119, 296-299.

Formal, S. B., Kent, T. H., May, H. C., Palmer, A., Falkow, S. \& LABREC, E. H. (1966). Protection of monkeys against experimental shigellosis with a living attenuated oral polyvalent dysentery vaccine. Journal of Bacteriology 92, 17-22.

Gamian, A. \& RomanowsKa, E. (1982). The core structure of Shigella sonnei lipopolysaccharide and the linkage between $\mathrm{O}$-specific polysaccharide and the core region. European Journal of Biochemistry 129, 105-109.

Harayama, S. \& Hazelbauer, L. (1982). A gene coding for a periplasmic protein is located near the locus for termination of chromosome replication in Escherichia coli. Journal of Bacteriology 151, 1391-1396.

Hashimoto-Gotoh, T., Franklin, F. C. H., Nordheim, A. \& Timmis, K. N. (1981). Specific-purpose plasmid cloning vectors. I. Low copy number, temperature-sensitive, mobilization-defective pSC101-derived containment vectors. Gene 16, 227-235. 
HrTchcock, P. J. \& Brown, T. M. (1983). Morphological heterogeneity among Salmonella lipopolysaccharide chemotypes in silverstained polyacrylamide gels. Journal of Bacteriology 154, 269277.

KADO, C. I. \& LIU, S. T. (1981). Rapid procedure for detection and isolation of large and small plasmids. Journal of Bacteriology 145, 1365-1373.

Kato, J., SUzUKi, H. \& Hirota, Y. (1984). Overlapping of the coding regions for $\alpha$ and $\gamma$ components of penicillin-binding protein $1 \mathrm{~b}$ in Escherichia coli. Molecular and General Genetics 196, 449-457.

Kenne, L., Lindberg, B., Petersson, K., Katzenellenbogen, E. \& RomanowsKa, E. (1980). Structural studies of the O-specific sidechains of the Shigella sonnei phase I lipopolysaccharide. Carbohydrate Research 78, 119-126

Kopecko, D. J., Washington, O. \& Formal, S. B. (1980). Genetic and physical evidence for plasmid control of Shigella sonnei form I cell surface antigen. Infection and Immunity 29, 207-214.

LaBrec, E. H., Schneider, H., Magnani, T. J. \& Formal, S. B. (1964). Epithelial cell penetration as an essential step in the pathogenesis of bacillary dysentery. Journal of Bacteriology 88, 15031518.

LaEmmLI, U. K. (1970). Cleavage of structural proteins during the assembly of the head of bacteriophage T4. Nature, London 227, 680685.

LENNOX, E. S. (1955). Transduction of linked genetic characters of the host by bacteriophage P1. Virology 1, 190-206.

MANDEL, M. \& HigA, A. (1970). Calcium-dependent bacteriophage DNA infection. Journal of Molecular Biology 53, 159-162.

Maniatis, T., Fritsch, E. F. \& SambrooK, J. (1982). Molecular Cloning: a Laboratory Manual. Cold Spring Harbor, NY: Cold Spring Harbor Laboratory.

MeL, D. M., Terzin, A. L. \& Vuksic, L. (1965). Studies on vaccination against bacillary dysentery. 3. Effective oral immunization against Shigella flexneri $2 \mathrm{a}$ in a field trial. Bulletin of the World Health Organization 32, 647-655.

Okamura, N., Nagai, T., Nakaya, R., Kondo, S., Murakami, M. \& Hisatsune, K. (1983). HeLa cell invasiveness and $O$ antigen of Shigella flexneri as separate and prerequisite attributes of virulence to evoke keratoconjunctivitis in guinea pigs. Infection and Immunity 39, 505-513.
Riley, L. W., Junio, L. N., Libaek, L. B. \& Schoolnik, G. K. (1987). Plasmid-encoded expression of lipopolysaccharide O-antigenic polysaccharide in enteropathogenic Escherichia coli. Infection and Immunity 55, 2052-2056.

Sansonetti, P. J., Kopecko, D. J. \& Formal, S. B. (1981). Shigella sonnei plasmids: evidence that a large plasmid is necessary for virulence. Infection and Immunity 34, 75-83.

Sansonetti, P. J., Kopecko, D. J. \& Formal, S. B. (1982). Involvement of a plasmid in the invasive ability of Shigella flexneri. Infection and Immunity 35, 852-860.

Sansonetti, P. J., Hale, T. L., Dammin, G. J., Kapfer, C., Collins, H. H., JR \& FORMAL, S. B. (1983). Alterations in the pathogenicity of Escherichia coli $\mathrm{K}-12$ after transfer of plasmid and chromosomal genes from Shigella flexneri. Infection and Immunity 39, 13921402.

Watanabe, H. \& NaKamura, A. (1985). Large plasmids associated with virulence in Shigella species have a common function necessary for epithelial cell penetration. Infection and Immunity 48, 260262.

Watanabe, H. \& Nakamura, A. (1986). Identification of Shigella sonnei form I plasmid genes necessary for cell invasion and their conservation among Shigella species and enteroinvasive Escherichia coli. Infection and Immunity 53, 352-358.

WeIsLANDER, L. (1979). A simple method to recover intact high molecular weight RNA and DNA after electrophoretic separation in low gelling temperature agarose gels. Analytical Bicchemistry 98, 305-309.

YaNisCH-PERron, C., Vieira, J. \& Messing, J. (1985). Improved M13 phage cloning vectors and host strains: nucleotide sequences of the M13 mpl8 and pUC19 vectors. Gene 33, 103-119.

Yoshimori, R. ROULland-Dussoix, D. \& Boyer, H. W. (1972). R factor-controlled restriction and modification of deoxyribonucleic acids: restriction mutants. Journal of Bacteriology 112, 1275-1279. 